\title{
The Academic Writing Challenges Faced by Saudi Students Studying at a University in New Zealand
}

\author{
Ayman Ankawi \\ English Language Institute, King Abdulaziz University \\ Computer Street, King Abdulaziz University, Jeddah 80204, Saudi Arabia
}

Received: June 15, 2020 Accepted: July 11, $2020 \quad$ Published: July 13, 2020

doi:10.5296/ijele.v8i2.17342 URL: https://doi.org/10.5296/ijele.v8i2.17342

\begin{abstract}
This study focused on academic writing challenges and its requirements, explored student perceptions and suggested ways in which their needs could be better met. The current study examined the obstacles of academic writing facing Saudi students in a New Zealand university. The study adopted a qualitative method approach in which 10 volunteer students were interviewed to learn their views and perceptions of academic writing skills in English and the questionnaire was used to collect students' demographic information. Also, what can be done to better prepare students for academic study at English medium universities. The students' attitude was not positive, which elicited the problem. The results revealed that the attitude of Saudi students towards learning and using the English language was not positive due to problems in teaching English, which resulted in students not prepared for the requirements of studying through the English language. It is also hoped that the results and recommendations issued by this study will benefit Saudi students, government departments in the Kingdom of Saudi Arabia, as well as English medium universities that accept students.
\end{abstract}

Keywords: academic writing challenges, attitude, literacy, perceptions 


\section{Introduction}

English has become extremely important for international students to improve their communication skills as the common language globally, which has led to an increase in students coming from non-English-speaking countries to obtain education in the West (Turner, 2011). One of the requirements for participation in academic discourse is that international students "positioned between different cultures and languages" (Turner, 2011, p. 12). How can students who are coming to demand education in the West overcome the requirements of living in a host country and adapting to new educational systems, social relationships, and academic literacy practices? Hence, it is important to know the perceptions of international students particularly Saudi students about studying English in institution of higher education in English medium universities. The main objective of this study is to study the factors that contribute to the challenges of academic writing for Saudi students at a university in New Zealand.

\subsection{Literature Review}

This section discusses some of the challenges facing international English as a Second Language (ESL) students who are studying at English-medium universities.

\subsubsection{International Students}

Social relationships and language skills are identified as essential factors for international students to adapt to living and studying in an English-speaking environment (Andrade, 2006). Internationally, the importance of learning English has become an increasing factor in the number of students coming from non-English speaking countries to English speaking countries (Turner, 2011). Researchers emphasize the social and academic problems facing international students in English-speaking universities, and they link this to their English language skills (Talebloo \& Bak, 2013). Sawer 2005 suggests in one of the studies that Asian students in Australia face difficulties in writing and speaking in English, which impedes them from active participation in the classroom and educational lessons. Many researchers attribute this issue to the previous experience of Asian students in a negative learning style more than that in Australian classes (Hui, 2005; Xiao \& Tianjin, 2006).

Helstein and Prescott (2004) note that the participation of Asian students in classroom discussions is largely hampered by the negative feeling that students hold when speaking English because of their lack of confidence. Sawir (2005) suggests in a study that Asian students who are studying in Australian universities face difficulties in writing and speaking in English, which also prevent them from actively participating in classrooms and educational programs. Saudi students are also accustomed to have passive style learning in Saudi Arabia, which can also be applied to these students. Consequently, it leads to weakness in reading and writing skills, especially academic writing and lack of confidence in the English language environment.

\subsubsection{International Students in New Zealand}

International students face difficulties and problems such as not having the appropriate 
English words to ask their lecturers and understanding the writing conventions of Western universities in general and in particular New Zealand universities because English is not their first language. According to the New Zealand Ministry of Education (MOE), students who are coming to study at universities from outside the country have become an important part of the New Zealand government's education policy (MOE, 2014). Therefore, international students need to understand the learning resources available in the host community and in the academic environment such as the student learning center in each university where assistance by appointment is free. Academic writing is a problem for many international students arriving in New Zealand, including Saudi students because it involves critical thinking and a high level of English.

\subsubsection{Saudi Students}

In an attempt to integrate itself into the global economy, Saudi Arabia recently opened its doors to foreign companies (Qobo \& Soko, 2010). There are few opportunities to speak, read, write, or listen to the English among Arab students, especially students from Saudi Arabia in their home countries.

The Saudis depend on their mother tongue and little attention is given to English or other languages. This is because the Saudi curriculum is mainly based on the Arabic language at all levels of students 'education (Saadi, 2012). They only speak Arabic at work but have few opportunities to speak English with foreign workers or visitors. Arab students prefer to listen and speak rather than read and write. This is not enough to help them write assignments successfully or pass their degrees, but it may be useful to get to know their classmates or to discuss academic readings or assignments. To write assignments successfully or pass their certificates, a better performance in academic writing is required (Gelb, 2012). Writing or reading in a language other than Arabic is not widely taught in the Saudi educational system (Elmoneif, 2005). Saudi students' difficulties in speaking English is a simple problem compared to the difficulties they face in academic discourse. Weak communication skills represent another challenge that may affect Arab students (Fadda, 2012). It also applies to Saudi students who are studying in New Zealand. They often lack confidence in pursuing their studies abroad because of these poor communication skills.

\subsection{Academic English}

International students, including Saudi students, must have a good understanding of the research materials being read and be able to paraphrase research materials and use them effectively to support their argument. Also, they should use appropriate vocabulary, appropriate style and effective organizational skills in their academic writing. Fukao and Fujii (2001) indicate that academic writing requires students to be able to integrate skills that include gathering information, reformulating and summarizing materials, organizing ideas in a logical order, editing, and finally proofreading. Adas and Bakir (2013) focus on the fact that the problem for international students is the lack of understanding of the English vocabulary. This also applies to Saudi students as they are learning English as a second language (ESL). Likewise, how Saudi students face problems and express their ideas effectively when writing in an academic style. 
Scarcella (2003) advocates that academic writing has specific linguistic features related to academic disciplines. Also, academic literacy includes the ability to acquire many types of skills such as higher thinking skills (critical thinking), communication skills, and research skills, not just the ability to read and write. Wang (2011) states that the context of the topic is largely influenced by the cultural background and social conditions of the author. Therefore, the social and cultural background of any international student, as well as a Saudi student, are reflected in their academic writings. Students must pay close attention to the expectations set by the lecturers / teachers and be aware of them in order to produce writing according to the criteria required to be proficient in academic writing (Irvin, 2010). Understanding writing skills in their first language (L 1) helps students transfer some writing skills such as outlining, rewriting, and summarizing to their second language (L 2) more easily. Although universities provide guidelines for academic writing, how can these guidelines be understood and used by students who need to apply these rules in academic writing? Reading this guide in itself is important to many second language students. This is one of the problems faced by international students, such as Saudi students.

\subsubsection{Difficulties Saudi Students Have with Academic English}

According to Grami and Alzughaibi (2012) statistics indicate that the performance of Saudi students is very poor in English in the Kingdom of Saudi Arabia and therefore affects their performance in other subjects taught in English. So, the challenge is even greater for those who are studying at an English medium university abroad like New Zealand. Students in Saudi Arabia are exposed to English for only a few hours a week during formal teaching. Saudi students hear a little spoken English because learning focuses on writing rather than speaking or listening to English at school (Al-Seghayer, 2014).

Academic writing requires students to write from a formal perspective, applying all rules are related to writing and using the correct method of citation when providing evidence for claims. Students who are not well equipped with good writing skills in general may find it difficult to write in academic writing (Sayidina, 2010). Saudi students do not benefit from the opportunity to read in English from electronic sources (Aljumah, 2012).

Students fail to understand lectures, ask questions, or discuss ideas among classmates in situations where students have poor listening skills. So, they do not share ideas as they fear suffering embarrassment in front of their peers while speaking in English. All these problems arise because students are not well prepared before they arrive in the country of study. In order to be able to learn and implement academic writing effectively in New Zealand universities, Saudi students must be able to understand spoken and written English. Also, improving listening and speaking about academic issues will improve their confidence in academic writing.

According to Grabe and Kaplan (2014), rhetorical styles of writing differ from one language to another due to the differences between cultures with regarding issues of rhetorical style. Therefore, reading academic texts is a challenge for Saudi students. Kaplan (1972) argues that interpretative writing in a second language presents a major challenge. For this reason, people always prefer to read and write texts built in rhetorical style related to their culture. 
Gomaa-Moulds (2010) emphasizes that students 'first language affects their target language. She also agrees that academic writing is the most difficult skill for English language learners. The readers become confused and find their language unusual even if the grammar and vocabulary are correct if the texts written in a rhetorical style are different from the method used in their mother tongue (Siti Hamin \& Mohammad, 2012).

\subsubsection{Other Difficulties Saudi Students Have}

There are numbers of other language-related problems discussed briefly in the following section besides English academic writing and speaking being considered a great challenge and problem to Saudi students.

\subsubsection{Difficulties with Grammatical Competence}

The Arabic language belongs to the family of the Semitic language and the grammar and rules are completely different from English (Sayidina, 2010). Moreover, all words in Arabic follow a grouping pattern using at least three consonants with vowels and in some cases an affix. Grammatical difficulties such as those illustrated in their spoken language may become permanent if they are not overcome before applying to study overseas, and these difficulties may prevail in their academic writing as a result.

An example of this is the difference in the use of vowels affecting Saudi students. Vowels are not important in Arabic and are not clear in Arabic writing while they are visible in writing in English (writing in English has more vowels than Arabic). Saudi learners tend to forget to include these letters when writing in English due to their lack of reliance on writing vowels explicitly. Researchers explain this tendency "vowel blindness" (Khan, 2013, p. 26). Some Saudi students who study in English need to be aware of the other differences between Arabic and English. Saudi students sometimes jump to hasty conclusions about grammar rules (Bacha, 2010).

\subsubsection{Difficulties with the Different Structure of Arabic and English}

Many languages, including Arabic, differ from English in style. This appears in academic writing for students when they try to clarify their points and ideas. Arabic tends to have more metaphors phrases and lengthier sentences than in English (Fadda, 2012). Moreover, the differences in reading and writing between Arabic and English are also difficult. According to Yiu (2009), students whose mother tongue has different structures than English face difficulties in studying an English course at their university. As a result, some international students, including Saudis, whose English is weak, face difficulties in understanding subjects taught in English-medium universities and the expected structure of academic articles.

\subsubsection{Difficulties with Difference in Genres}

Differences in genre are one reason to explain why it is difficult to write in English for speakers of other languages, including Saudi students. According to Peters (2008, p. 3) genres are "inherently dynamic rhetorical structures that can be manipulated according to the conditions of use". Hyland (2008) argues, analyzing language acquisition through a genre perspective helps us understand organizational patterns of assignment. While all possibilities 
are available to all users, what is considered logical, attractive, appropriate or good, the organization often differs in academic writing between cultures (Hyland \& Tse, 2005). Researchers suggest that, compared to many languages, academic texts in English tend to be more explicit in terms of structure and purposes, " to be less tolerant of digressions, to be more cautious in making claims, and to use more sentence connectors" (Hyland \& Tse, 2005, p. 548). Bacha (2010) clearly states that there are different ways of organizing ideas and structuring arguments in different languages. Therefore, this organization may have implications for academic writing teachers. These differences are important for teachers to point and teach before students leave Kingdom of Saudi Arabia to study abroad.

\subsubsection{Socio-cultural Differences}

Gee (2005) mentions that being, for students who travel abroad, by themselves without their families often becomes a major challenge on its own and can have dangerous effects on their ability to learn and be open to new ideas and perspectives.

International students, including Saudis, bring a set of cultural and experiential differences to the task of academic writing (Leki and Carson, 1997)). The new study environment is completely different from the original environment for Saudi students. Sayyidna (2010) states that the university curriculum may address topics and issues that are not related to the interests of the student and seem to be far from the reality of his country of origin. A study conducted by Al-Khairy (2013, p. 366) lists the common factors perceived as demotivating by Saudi students and hence negatively impacting perception of learning English. These factors are:

1. Insufficient exposure to English in Saudi Arabia

2. Lack of motivation in Saudi Arabia

3. Lack of information in Saudi Arabia about the educational institutes at which students will study

4. Inadequate teaching curricula in Saudi Arabia

5. Poor teaching methodologies in Saudi Arabia

The Saudis recently gained an important understanding and acceptance of English, and it is seen as necessary to remove barriers to communicate with foreigners, and for the country's social, scientific and economic development (Javid, Farooq, \& Gulzar, 2012). Students who grow up in Saudi Arabia have a limited exposure to English, which affects their motivation to improve their English language skills. Lack of communication with native speakers of English, lifestyle, and lack of guidance to help them in English, and the family's pressure on their children to study abroad are also the main reasons that lead to a poor understanding of English in particular academic writing at all levels (Intakhabalam, 2011, p. 1256). Therefore, Saudi students who study abroad in countries such as New Zealand often do so in the interest of their parents, tend to be unwilling to study. 


\subsection{English Teachers and Academic Writing in Saudi Arabia}

Most of the foreign teachers who teach in Saudi Arabia are not themselves English native speakers. Teachers of English in Saudi Arabia may come from other Islamic countries such as Pakistan, India, and Malaysia (Al-Seghayer, 2014). They also come from various Islamic countries surrounding the Kingdom of Saudi Arabia, such as Jordan, Syria, and Egypt (Bacha, 2010). Al-Hazmi (2003) states that most teachers in Saudi Arabia can only provide limited language knowledge to students due to their lack of English skills. This is either because the curriculum offered to them is limited or they themselves are alumni of the same educational system and therefore lack proficiency in English. Student vocabulary will be affected because poor teaching from teachers negatively affecting student learning. It is reasonable for students to rely solely on the teacher, given that the teacher is the only source of English assistance at the educational institute. Teachers are more likely to avoid class discussions and focus instead on grammar if they are not confident in their English (Saadi, 2012). The teachers explain everything in the text as well as grammatical rules while students listen passively, take notes, and answer questions in Arabic. such these outdated methods does not encourage students to actively participate in class discussions or search the Internet for books or articles, and thus students do not prepare for the requirements of academic writing (Yiu, 2009). So, this hurts Saudi students who study in countries outside the Kingdom of Saudi Arabia like New Zealand where students are expected to understand the lectures and play a more active role in the questions and discussions.

Bacha (2012) states that Arabic is taught by memorizing the Holy Quran and classical poetry. Sayidina (2010) argues that methods such as memorizing, and distance learning are a mirror of the literacy practices used by Arab countries. As noted, Saudi students may lack a broad foundation in the English language because many teachers in Saudi Arabia focus only on teaching grammar. Because many teachers focus on teaching the basics of grammar and not focusing on spoken communication skills, most students in Saudi Arabia are unable to use English as soon as they travel abroad to study (Al-Hasouni, 2012). Most teachers in Saudi Arabia do not seem to be able to increase students' proficiency in academic writing because they tend to focus on vocabulary, but they do not focus on developing academic writing skills.

There are a number of reasons that mean Saudi Arabia may not always be the preferred destination for fluent English-speaking instructors. Limitations such as having a formal dress code like "abaya", and prohibition of alcohol and pork as well as rules against gender mixing are just some of the issues that might deter native English-speaking teachers from travelling to and working in Saudi Arabia. Also, teachers are aware that they might find themselves teaching in remote locations.

\subsubsection{Lack of Confidence for Learning English}

It is possible that the teachers themselves may lack confidence in teaching speaking or writing because many English teachers are not native English speakers. Researches indicate that lack of confidence affects students' ability to learn English (Fadda, 2012; Qobo \& Soko, 2010; Robertson, Line, Jones, \& Thomas, 2000). It is not surprising that Saudi students also 
show low levels of confidence towards learning English such as reading and writing (Fadda, 2012), perhaps because their teachers also lack confidence. Yiu (2009) considers that factors such as low confidence lead to a lack of motivation to learn English, which also leads to an inability to learn English and understand it properly.

\subsubsection{Lack of Motivation for Learning English}

Motivation is the attribute that motivates us to do or not do something (Broussard \& Garrison, 2004). It is believed that motivation "energizes " human behavior and "gives it direction", and thus it constitutes an important dimension in language learning (Bahous, Bacha \& Nabhani, 2011, P. 34).

There is a tendency for most Saudi students to stay together rather than developing relationships with local students, which leads to less exposure to enjoy the benefits of language learning that can be gained from living with a home stay family or with New Zealand colleagues. They choose to live in a situation where they are forced to communicate in English most of the time if they are more eager to learn English. Many Saudi students prefer to share or stay with other Arabic speakers instead.

Many Saudi students view English as unimportant for many reasons. English is not often used in Saudi classrooms. The main reason why Saudi students learn English in Kingdom of Saudi Arabia is to pass exams (Saadi, 2012). Also, many Saudi students have a negative attitude due to lack of confidence and motivation towards learning English (Bahous et al., 2011).

Factors, some of which are social and some are academic, affect Saudi students' decision to study in an English-medium university as it is the parents 'desire rather than the students' desire and the tendency of Saudi students to live together instead of mixing with English speakers. International students in general and Saudi students in particular face many challenges in English. Their weak foundations in English as a foreign language and a weak foundation for writing starting in Saudi Arabia are examples of challenges in English.

More than $25 \%$ of the budget now focuses on education as there were 8 public universities in Saudi Arabia in 2006, and by 2009, this number increased to 25, indicating the increasing importance of higher education in the Kingdom of Saudi Arabia (Education, 2015). Today, the Kingdom of Saudi Arabia is investing in human resources at an improved rate compared to the past, and this expansion of educational institutions has led to the growth of English as the medium of instruction.

Although this article is limited to the experience of Saudi students, it is, of course, only one aspect of the broad global picture that reflects the challenges facing English speakers of a second language in Arab universities. The literature does not show any studies specifically addressing the situation of Saudi students in New Zealand, hopefully hope this study will help bridge this gap. Therefore, the aim of this study is to identify the academic writing challenges facing Saudi students at one New Zealand university. The literature review has failed to find any research that specifically addresses the situation of Saudi students in New Zealand. 


\section{Method}

\subsection{Research Methodology}

This study used a qualitative research method, which aims to address the current understanding of the challenges that Saudi Arabian students face in English academic writing. This study was conducted using interviews and a questionnaire to collect data from participants. Interviews were mainly used to inform this study and answer the research questions while questionnaires were used to provide an overview and to gather demographic data.

According to the researchers (Creswell, 2013; Green, Melbourne Australia RIMT University Press/2002; Merriam, 2009) the interpretative approach looks at the facts as multiple constructions or interpretations instead of one truth. This study mainly relied on an interpretative approach that fits the selection of interviews as the main method of data collection. Based on descriptions, observations, and the use of an interpretative approach, the topic can enhance the understanding of human experiences, perceptions, intentions, motivations, and behaviors of study participants. Patton (1990, p. 375) stated that "interpretation includes interpreting results, answering" why "questions, attaching importance to specific results, and setting patterns in an analytical framework." The use of an interpretative approach requires a dialogue between the researcher and the research participants to collaboratively reach a complete picture. This is important to understand the challenges of academic writing among Saudi students who have their own experiences with academic writing. Depending on their education, upbringing, and world worldview, interviewing the participants was important for this study to get an accurate picture of these students 'academic writing experience.

\subsection{Participants}

The criteria for participation in this study are that Saudi students must have studied in the Kingdom of Saudi Arabia and must now be at the University of New Zealand. The demographic survey of this study included 65 students from the Kingdom of Saudi Arabia, and they must be currently studying at one New Zealand University. International Students' Office has identified 150 students from Saudi Arabia and participants have been contacted in various ways to ensure a high response rate. To increase the response rate, this study used snowball technique, as potential participants were also asked to invite their friends from Saudi Arabia, who are currently studying at the university. This study sought the cooperation of the International Students' Office to send an invitation to those students who request to volunteer to participate in the research. The students who volunteered were contacted via email.

Sharing information on social media is beneficial (Knight, Pearson, 2005). One of the ways for contacting potential participants for this study was to contact Saudi Arabian clubs and association in New Zealand such as Auckland, Hamilton, Wellington, and cities on the South Island, and they have a Facebook page. These clubs are the first point of contact for all Saudi students, and their roles are to sponsor Saudi students in New Zealand and provide them with 
social and cultural services. The Social Club for Saudi Students in Auckland has agreed to publish the survey questionnaire online, which also provided information related to interviews and the ways in which participants can participate on its Facebook page (the Saudi Auckland Club). Clubs were created by the government of the Kingdom of Saudi Arabia to provide students with various support services such as educational and social support and give them an opportunity to participate in outdoor and indoor sports activities. This method was followed because some students may have missed the invitation to participate in the research that the International Student Office sent to its official email at the university.

\subsection{Data Collection Instruments}

\subsubsection{Online Survey}

The online survey for this study consists of closed- and open-ended questions. This study used an online survey website called SurveyMonkey (www.surveymonkey.com), which provides a cloud service and it was chosen because it is customizable and widely known. Therefore, participants trusted the link when it was sent to them by email.

There were 16 multiple-choice questions and one open-ended question. Participants were asked about their demographic characteristics such as age, gender and duration of their English study before they were admitted to the New Zealand university. Participants were asked to provide answers related to their experience and their academic background. Self-administered questionnaires were used in this study because they were convenient for the research participants.

The questionnaire was presented in Arabic and English to ensure that the participants understood the questions. Translation of the questionnaires from English to Arabic was done by the researcher and the accuracy of the translation was reviewed by an Arabic $\mathrm{PhD}$ student also studying at the same university.

\subsubsection{Interviews}

Interviews with volunteers helped me to broaden my understanding of the challenges these students face. Table 1 shows the demographic information for students who volunteered for the interviews.

\begin{tabular}{|c|c|c|c|c|}
\hline Participant & Age & Specialty & Gender & $\begin{array}{l}\text { How long ago did you arrive in } \\
\text { NZ }\end{array}$ \\
\hline $\mathrm{P} 1$ & $25-30$ & IT & Male & more than 12 months \\
\hline $\mathrm{P} 2$ & $18-24$ & $\begin{array}{l}\text { Computer and mobile } \\
\text { system engineering }\end{array}$ & Male & more than 12 months \\
\hline P3 & $25-30$ & Business Administration & Male & more than 12 months \\
\hline $\mathrm{P} 4$ & $25-30$ & $\begin{array}{l}\text { Master of Computer and } \\
\text { Information Sciences }\end{array}$ & Male & more than 12 months \\
\hline P5 & $31-34$ & Computer sciences & Male & more than 12 months \\
\hline
\end{tabular}




\begin{tabular}{|l|l|l|l|l|}
\hline P6 & $18-24$ & Health science & Male & more than 12 months \\
\hline P7 & $31-34$ & Bachelor of Business & Male & more than 12 months \\
\hline P8 & $18-24$ & $\begin{array}{l}\text { Bachelor of Business - } \\
\text { Design Major }\end{array}$ & Male & more than 12 months \\
\hline P9 & $25-30$ & Finance & Male & more than 12 months \\
\hline P10 & $25-30$ & $\begin{array}{l}\text { Business Information } \\
\text { System }\end{array}$ & Male & more than 12 months \\
\hline
\end{tabular}

In this study the participants were all Saudi Arabian and studying at the undergraduate level except for one of the ten participants who was a postgraduate student. They were asked to volunteer, and the first 10 to do so were chosen for the interviews as they all had the characteristics and context needed. This study used the semi-structured interviews. These interviews employ a guideline for questions asked but allow the researcher the freedom to follow up points as necessary within a given structure (Thomas, 2010). In this particular study, semi-structured interviews allowed me, as the researcher, to obtain participants' perceptions and opinions on the challenges of academic writing and also the reasons and stories behind these challenges.

As the researcher I asked a question to participants and from their answers, I formulated specific questions on the topic to explore the challenge of academic writing that the participants face and their experiences. I was interested to know what the tools and strategies were that the participants used to overcome the challenges of academic writing. Other questions during the interviews mainly asked participants about the role of the Student Learning Centre (SLC), the students' level of preparation for academic writing, and most importantly, the challenges they face in academic writing at university now. Interviews were planned to take between 45 minutes to an hour to allow for meaningful sharing of experiences that the students face with regards to academic writing.

\subsection{Data Analysis}

This study adopted an interpretive approach from Elliott and Timulak (2005), using the following steps.

1- Data preparation: The first step was to transcribe the interviews and enter this data into a document that makes it easy to follow and read. After transcribing and listening to the interviews several times I became more familiar with the data.

2- Meaning units: In the second step the data was divided into distinctive meaning units. Delineating the meaning units can shorten them by getting rid of redundancies that do not change the meaning contained in them.

3- Organizing structure: This research analyzed the data that has been collected, then analyzed and divided the meaning into several units, later on I organized and collected the data into generated themes.

4- Generating categories: As an interpretive technique, the study used coding in order to 
organize the data and provide a means of introducing interpretations.

Include in these subsections the information essential to comprehend and replicate the study. Insufficient detail leaves the reader with questions; too much detail burdens the reader with irrelevant information. Consider using appendices and/or a supplemental website for more detailed information.

\section{Results and Discussion}

This section brings together all the findings and discusses the implications of this study. The aim of this study is to identify the academic writing challenges that Saudi Arabian students are facing.

\subsection{Professional Development}

Results from the questionnaire and interviews show most Saudi Arabian students intend to stay in New Zealand after finishing their study to improve their speaking and academic writing skills. In addition, they aim to continue with their studies in order to have an opportunity to get a good job with a high salary when they return to KSA, as jobs depend on the level of the postgraduate degree, level of speaking and writing skills, where all foreign companies in Saudi Arabia request to have all letters of credit been written in English and the country he or she graduates from, as it emphasizes that Saudi Arabia has more recently opened its doors to foreign business in an effort to integrate itself into the global economy (Qobo \& Soko, 2010). Adult professionals are looking to learn English in order to exploit the advantage English provides in the commercial world.

\subsection{Preparation for Study in English}

Results from the questionnaire reveal that a minority of the students had English qualifications (e.g., IELTS, TOFEL) from Saudi Arabia before coming to New Zealand, while other students obtained qualifications through enrolment in English courses in New Zealand. This lack of English preparation prior to departure from KSA appears to be due to the poor-quality English preparation courses available to students particularly writing skill. Students who enrolled for these courses found them of little benefit as they did not address their academic English needs and provided only basic English. Previous studies and research have shown that students' lack of motivation is a result of external factors like the learning environment and teacher's methodology (Simone, 2012). Because students do not learn English well, they are not confident about using it.

\subsection{Help with English Language}

Saudi students in New Zealand can improve their English especially academic writing as follows:

\subsubsection{Visiting the Student Learning Centre}

International students studying in NZ face a number of challenges (MoE, 2014). Some of 
these challenges and obstacles are language barriers (due to the majority of English-speaking students arriving from China, India, the Middle East including Saudi Arabia where English is not widely spoken). They need to understand the learning resources available in the host community and in the academic environment such as the Student Learning Centre at each university where help is available by appointment and free of charge.

This Centre aims to support them in their English. As Saudi students face difficulties in English especially academic writing, most of them come to this Centre looking for help with their writing. They are shown how to proofread their assignments, paraphrase, and structure their writing, and check the grammar. According to one participant

They will teach you how to write a conclusion, which is paraphrasing everything that you have written in one or two paragraphs.[..], I think that SLC for starting, it was beneficial for me the first time, I will go again when I need to check my essay origination. (Participant 6)

Students had been told in orientation to visit the Student Learning Centre. Despite lectures' encouragement, some students did not visit the center founding that the help offered by their lecture was enough. Others depended on another source to help them with English, for example private tutors.

\subsubsection{Employing Private Tutors}

Some students are looking to improve their academic English writing in a short period of time, rather than doing long term courses. They look for a private tutor because it is easy to arrange the lessons according to their free time, especially in the evening after finishing their lectures. Furthermore, private tutors are more useful since they concentrate on one student and focus on the problems and the difficulties of one student to help him or her to overcome the challenges, he/she faces and improves his/ her academic writing skills.

Saudi students found that using a private tutor is a very effective method in enhancing their language skills.

I tried to look for an English teacher specializing in academic writing, I found a lot of teachers, and I was looking at their background and qualifications. Then, I found a teacher from New Zealand who has a master's degree in language whom I contacted. I learnt a lot from him about academic writing. (Participant 7)

\subsubsection{Helping Themselves}

Students can help themselves by reading books or using internet resources. Books and resources for academic or general English can be beneficial if the reader can follow the authors' explanations about the academic writing and transfer these ideas to their own writing. However, it is not easy to find books that are compatible with the required level of English academic writing, and also explain academic writing requirements in a way that these students find comprehensible. Hyland (2008) analyzing language acquisition through a genre point of view assists us in understanding the organizational patterns of assignments. According to Fukao and Fujii (2001) academic writing requires students to have the ability to integrate skills which include gathering information, paraphrasing and summarizing resources, 
organizing ideas in a logical order, editing and finally proofreading.

\subsection{Issues Raised by Students}

According to the findings the challenges Saudi students are facing with English, especially academic writing, can be summarized as follows:

- Lack of vocabulary especially academic writing vocabulary.

- The use of formal language.

- Difficulties in paraphrasing and summarizing articles.

- Difficulties in finding references correctly and finding appropriate articles.

The ministry of Saudi Arabia realizes that English is the international medium of communication and in order to increase cooperation with other nations and facilitate the transfer of scientific and technological knowledge, levels of English proficiency must be increased (Alzayid, 2012; Ur Rahman \& Alhaisoni, 2013)..

\section{Conclusion}

This study indicates that the following recommendations could improve Saudi Arabian student English proficiency.

Qualified English teachers are the main requirement to improve English skills for Saudi students. They should be able to teach the required academic English writing skills and be able to help the students understand what is involved in academic writing. Previous studies in KSA (Alkubaidi, 2014; Almutairi, 2007; Alrabai, 2014; Fareh, 2010; Rajab, 2013) point out teachers in KSA use Arabic to teach English. Accordingly, this has led to reliance of the students on inappropriate learning strategies such as memorization and rote learning. In addition, Alhawsawi (2014) adds that the teachers' use of Arabic may be due to their own lack of knowledge and confidence in using English, or it may simply be a choice to make their job easier but English cannot be taught well using Arabic only.

Teaching English in KSA is teacher-centered, not student-centered, therefore there should be changes in this method of learning in order to give the students the opportunity to be more actively involved in language classes. Students could be required to present seminars and complete assignments (Ahmad, 2014; Alkubaidi, 2014; Alrabai, 2014; Fareh, 2010; Rajab, 2013). According to Al-Harbi (2017) one of the main features of the pre-university and university level education system is the issue of recalling, they encourage students to memorize what they have learned instead of being motivated to think critically. She adds that the students' previous education is a reason for the difficulties they face in studying academic writing.

According to Al-Johani (2009), Almutairi (2007), Fareh (2010) and Intakhabalam (2011) students lack motivation and teacher do little to address this. Ways must be found to encourage and motivate students to learn English. For example, they could provide overseas 
trips to English-speaking countries. The lack of an environment in which they can practice their use of English effectively is one of the challenges that the students face (Alqahtani, 2011; Khan, 2013). In addition, schools and universities should provide facilities where students can practice English for several hours weekly and hold workshops that include fluent English speakers in order to allow the students to practice the English skills.

The Ministry of Education needs to oversee the development of facilities aimed at preparing KSA students for study in English medium institutions of higher education. The facilities will be able to address the issues identified by students in this study.

\subsection{Limitations}

There are three main limitations in this study. First, this study had only 65 Saudi participants for the online survey. Following this, only 10 participants were interviewed. Due to this small sample size the participants' experiences cannot be generalized to another group of Saudi students in New Zealand, as the findings might be unique to the relatively few Saudi students included in this particular research study. In addition, no female students were interviewed so this study only presents the male perspective.

\section{Acknowledgments}

I would like to thank Basim Alamri and the anonymous reviewers for their suggestions and contribution to my study.

\section{References}

Adas, D., \& Bakir, A. (2013). Writing difficulties and new solutions: Blended learning as an approach to improve writing abilities. International Journal of Humanities and Social Science, 3(9), 254-266.

Ahmad, A. M. (2014). Kumaravadivelu's framework as a basis for improving English language teaching in Saudi Arabia: Opportunities and challenges. English Language Teaching, 7(4), 96-110. https://doi.org/10.5539/elt.v7n4p96

Alharbi, N. (2017). An investigation into the academic writing: Difficulties of Saudi Postgraduate Students. (unpublished doctoral dissertation), University of Exeter, UK.

Al-Hazmi, S. (2003). EFL teacher preparation programs in Saudi Arabia: Trends and challenges. TESOL Quarterly, 37(2), 341-344. https://doi.org/10.2307/3588509.

Al-Johani, H. M. (2009). Finding a way forward: The impact of teachers' strategies, beliefs and knowledge on teaching English as a foreign language in Saudi Arabia. (Unpublished doctoral dissertation). University of Strathclyde, Glasgow, United Kingdom.

Al-Khairy, M. H. (2013). English as a foreign language learning demotivational factors as perceived by Saudi undergraduates. European Scientific Journal, 9(32), 365-382. 
Al-Seghayer, K. (2014). The four most common constraints affecting English teaching in Saudi Arabia. International Journal of English Linguistics, 4(5), 17-26. https://doi.org/10.5539/ijel.v4n5p17

Alhaisoni, E. (2012). A Think-aloud Protocols investigation of Saudi English major students' writing revision strategies in L1 (Arabic) and L2 (English). English Language Teaching, 5(9), 144. https://doi.org/10.5539/elt.v5n9p144

Alhawsawi, S. (2014). Investigating student experiences of learning English as a foreign language in a preparatory programme in a Saudi university. (Unpublished doctoral dissertation). University of Sussex, Brighton, UK.

Aljumah, F. H. (2012). Saudi learner perceptions and attitudes towards the use of blogs in teaching English writing course for EFL majors at Qassim university. English Language Teaching, 5(1), 100-116. https://doi.org/10.5539/elt.v5n1p100

Alkubaidi, M. (2014). The relationship between Saudi English major university students' writing performance and their learning style and strategy use. English Language Teaching, 7(4), 83-95. https://doi.org/10.5539/elt.v7n4p83

Almutairi, N. H. (2007). The influence of educational and sociocultural factors on the learning styles and strategies of female students in Saudi Arabia. (Unpublished doctoral dissertation). University of Leicester.

Alqahtani, M. (2011). An investigation into the language needs of Saudi students studying in British postgraduate programmes and the cultural differences impacting on them. (Unpublished doctoral dissertation). University of Southampton.

Alrabai, F. (2014). A model of foreign language anxiety in the Saudi EFL context. English Language Teaching, 7(7), 82-101. https://doi.org/10.5539/elt.v7n7p82

Alzayid, A. (2012). The role of motivation in the L2 acquisition of English by Saudi students: A dynamic perspective. (published doctoral dissertation). Southern Illinois University, Carpondale.

Andrade, M. S. (2006). International students in English-speaking universities adjustment factors. Journal of Research in International Education, 5(2), 131-154. https://doi.org/10.1177/1475240906065589

Bacha, N. N. (2010). Teaching the academic argument in a university EFL environment. Journal of English for Academic Purposes, 9(3), 229-241. https://doi.org/10.1016/j.jeap.2010.05.001.

Bacha, N. N. (2012). Disciplinary writing in an EFL context from teachers' and students' perspectives. International Journal of Business and Social Science, 3, 233-250.

Bahous, R., Bacha, N. N., \& Nabhani, M. (2011). Motivating students in the EFL classroom: A case study of perspectives. English Language Teaching, 4(3), 33-43. https://doi.org/10.5539/elt.v4n3p33 
Broussard, S. C., \& Garrison, M. (2004). The relationship between classroom motivation and academic achievement in elementary-school-aged children. Family and Consumer Sciences Research Journal, 33(2), 106-120. https://doi.org/10.1177/1077727x04269573

Creswell. (2009). Research design: Qualitative, quantitative, and mixed methods approaches. SAGE Publications, Incorporated.

Creswell. (2013). Qualitative inquiry and research design. Thousand Oakes: CA, Sage Publications, Incorporated.

Culture, A. I. T. A. (n.d.). Pre-arrival task 1 - An Introduction to Academic Culture. Retrieved 2015, from https://www.kcl.ac.uk/study/elc/offerholders/Pre-sessional/Pre-arrival1AnIntroductiontoAcad emicCulture.pdf

Education, M. O. E.-H. (2015). About government universities. Retrieved from http://he.moe.gov.sa/en/studyinside/Government-Universities/Pages/default.aspx

Elliott, R., \& Timulak, L. (2005). Descriptive and interpretive approaches to qualitative research. In J. Miles \& P. Gilbert (Eds.), A handbook of research methods for clinical and health psychology (pp. 147-159). Oxford University Press.

Elmoneif, A. I. (2005). The Kingdom of Saudi Arabia in world politics: Oil, Islam and international peace. ProQuest, UMI Dissertations Publishing. Howadr Universty, USA.

Fadda, H. (2012). Difficulties in academic writing: From the perspective of King Saudi University postgraduate students. English Language Teaching, 5(3), 123-130. https://doi.org/10.5539/elt.v5n3p123

Fareh, S. (2010). Challenges of teaching English in the Arab world: Why can't EFL programs deliver as expected? Procedia-Social and Behavioral Sciences, 2(2), 3600-3604. https://doi.org/10.1016/j.sbspro.2010.03.559

Fukao, A., \& Fujii, T. (2001). Investigating difficulties in the academic writing process: Interview as a research tool. ICU Language Research Bulletin, 16, 29-40.

Gee, J. P. (2005). The new literacy studies: From "socially situated" to the work of the social. In D. Barton, M. Hamilton, \& R. Ivonac (Eds.), Situated literacies: Reading and writing in context (2nd ed., pp. 177-194). London, England: Routledge.

Gelb, C. (2012). Cultural issues in the higher education classroom. Retrieved 2015, from http://www.studentpulse.com/articles/661/2/cultural-issues-in-the-higher-education-classroo $\mathrm{m}$

Gomaa-Moulds, L. (2010). 5 Writing trouble spots for ESL students of Arabic. Retrieved 2015, from http://works.bepress.com/cgi/viewcontent.cgi?article=1003\&context=lina_gomaa-moulds

Grabe, W., \& Kaplan, R. B. (2014). Theory and practice of writing: An applied linguistic perspective. New York, NY: Routledge. 


\section{$\triangle$ Macrothink}

International Journal of English Language Education

ISSN 2325-0887

Grami, M. A., \& Alzughaibi, M. G. (2012). L1 transfer among Arab ESL learners: theoretical framework and practical implications for ESL teaching. Theory and Practice in Language Studies, 2(8), 1552-1560. https://doi.org/10.4304/tpls.2.8.1552-1560

Green, P. (Ed.). (2002). Slices of life: Qualitative research snapshots. Melbourne: RMIT University Press.

Hellstén, M., \& Prescott, A. (2004). Learning at university: The international student experience. International Education Journal, 5(3), 344-351.

Hui, L. (2005). Chinese cultural schema of education: Implications for communication between Chinese students and Australian educators. Issues in Educational Research, 15(1), 17-36.

Hyland, K. (2008). Genre and academic writing in the disciplines. Language Teaching, 41(4), 543-562. https://doi.org/10.1017/s0261444808005235

Hyland, K., \& Tse, P. (2005). Hooking the reader: a corpus study of evaluative that in $\begin{array}{lllll}\text { abstracts. English for } & \text { Specific } & \text { Purposes, } & \text { 24(2), }\end{array}$ https://doi.org/10.1016/j.esp.2004.02.002

Intakhabalam, K. (2011). Learning difficulties in English: Diagnosis and pedagogy in Saudi Arabia. Educational Research, 2(7), 1248-1257.

Irvin, L. L. (2010). What is "Academic" writing? In Writing spaces: Readings on writing (Vol. 1), pp. 3-17. West Lafayette, IN: Parlor Press

Javid, C. Z., Farooq, U., \& Gulzar, M. A. (2012). Saudi English-major undergraduates and English Teachers' perceptions regarding effective ELT in the KSA: A comparative study. European Journal of Scientific Research, 85(1), 55-70.

Kaplan, R. B. (1972). The anatomy of rhetoric: Prolegomena to a functional theory of rhetoric; essays for teachers (Vol. 8): Center for curriculum development.

Khan. (2013). Embedded vowels: Remedying the problems arising out of embedded vowels in the English writings of Arab learners. RELC Journal, 44(2), 233-251. https://doi.org/10.1177/0033688213488464

Knight, M. B., \& Pearson, J. M. (2005). The changing demographics: The diminishing role of age and gender in computer usage. Journal of Organizational and End User Computing, 17(4), 49-65. https://doi.org/10.4018/joeuc.2005100103

Leki, I., \& Carson, J. (1997). "Completely different worlds": EAP and the writing experiences of ESL students in university courses. TESOL Quarterly, 31(1), 39-69. https://doi.org/10.2307/3587974

Merriam, S. B. (2009). Qualitative research: A guide to design and implementation. USA: John Wiley \& Sons.

MOE. ( 2014). Foreign Fee-Paying Students in New Zealand: Trends. New Zealand Ministry 
of

Education.

Retrieved

from

https://www.educationcounts.govt.nz/_data/assets/pdf_file/0009/6975/Foreign-Fee-Paying-S tudents-in-NZ-Trends.pdf

Patton, M. Q. (1990). Qualitative evaluation and research methods. USA: SAGE Publications, inc.

Peters, M. A. (2008). Academic writing, genres and philosophy. Educational Philosophy and Theory, 40(7), 819-831. https://doi.org/10.1111/j.1469-5812.2008.00511.x

Qobo, M., \& Soko, M. (2010). Saudi Arabia as an Emerging Market: Commercial Opportunities and Challenges for South Africa: South African Institute of International Affairs.

Rajab, H. (2013). Developing speaking and writing skills of L1 Arabic EFL learners through teaching of IPA phonetic codes. Theory and Practice in Language Studies, 3(4), 653-659. https://doi.org/10.4304/tpls.3.4.653-659

Robertson, M., Line, M., Jones, S., \& Thomas, S. (2000). International students, learning environments and perceptions: A case study using the Delphi technique. Higher education research and development, 19(1), 89-102.

Saadi, I. A. (2012). An examination of the learning styles of Saudi preparatory school students who are high or low in reading achievement. (Unpulished doctoral dissertation).Victoria University Melbourne, Australia.

Sawir, E. (2005). Language difficulties of international students in Australia: the effects of prior learning experience. International Education Journal, 6(5), 567-580.

Sayidina, A. (2010). Transfer of L1 cohesive devices and transition words into L2 academic texts: The case of Arab students. RELC Journal, 41(3), 253-266. doi:10.1177/0033688210380569

Scarcella, R. (2003). Academic English: A conceptual framework. The University of California Linguistic Minority Research Institute. (Unpulished doctoral dissertation). University of California: Technical report 2003-1. Irvine: University of California.

Simone, J. (2012). Addressing the marginalized student: the secondary principal's role in eliminating deficit thinking. (Unpulished doctoral dissertation) University of Illinois at Urbana-Champaign.

Siti Hamin, S., \& Mohammad, I. (2012). Rhetorical awareness and jordanian EFL students' expository writing. European Scientific Journal, 8(260-275).

Talebloo, B., \& Bak, R. B. (2013). Challenges faced by international postgraduate students during their first year of studies. International Journal of Humanities and Social Science $3(138-145)$.

Tas, E. (2010). Current trends in academic writing. Procedia-Social and Behavioral Sciences, $3,121-126$. 
Thomas, G. (2010). How to do your case study: A guide for students and researchers. Sage. Publications INC.

Turner, J. (2011). Language in the academy. Multilingual matters.

Ur Rahman, M. M., \& Alhaisoni, E. (2013). Teaching English in Saudi Arabia: Prospects and challenges. Academic Research International, 4(1), 112-118.

Wang, C.-M. (2011). Instructional design for cross-cultural online collaboration: Grouping strategies and assignment design. Australasian Journal of Educational Technology, 27(2), 243-258. https://doi.org/10.14742/ajet.968

Xiao, L., \& Tianjin, P. (2006). Bridging the gap between teaching styles and learning styles: A cross-cultural perspective. TESL-EJ, 10(3), 1-15.

Yiu, R. H. H. (2009). Disciplinary writing: a case study of Hong Kong undergraduates undertaking their writing tasks. University of Leicester, United Kingdom.

\section{Copyright Disclaimer}

Copyright for this article is retained by the author(s), with first publication rights granted to the journal.

This is an open-access article distributed under the terms and conditions of the Creative Commons Attribution license (http://creativecommons.org/licenses/by/3.0/). 